\title{
Population dynamics of Euryoryzomys russatus and Oligoryzomys nigripes (Rodentia, Cricetidae) in an Atlantic forest area, Santa Catarina Island, Southern Brazil
}

\author{
Pâmela Castro Antunes ${ }^{1}$ \\ Marilena Altenfelder Arruda Campos ${ }^{2}$ \\ Luiz Gustavo Rodrigues Oliveira-Santos ${ }^{1}$ \\ Maurício Eduardo Graipel $^{1^{*}}$ \\ ${ }^{1}$ Departamento de Ecologia e Zoologia, Centro de Ciências Biológicas \\ Universidade Federal de Santa Catarina, CEP 88040-970, Florianópolis - SC, Brasil \\ ${ }^{2}$ Instituto Nacional de Pesquisas da Amazônia, Laboratório de Etnoecologia Indígena \\ Manaus - AM, Brazil \\ *Corresponding author \\ graipel@ccb.ufsc.br
}

\begin{abstract}
The population dynamics and reproductive issues of two species of rodents of the family Cricetidae, Rice Rats (Euryoryzomys russatus) and Pygmy Rice Rats (Oligoryzomys nigripes), were studied for 24 months in an Atlantic Forest area in southern Brazil. Euryoryzomys russatus presented density-dependent population fluctuation, and recruitment was positively associated with temperature. Oligoryzomys nigripes displayed the lowest abundance, greatest population fluctuation and shortest permanence time. Abundance and survival were found to be negatively correlated with temperature. The sex ratio was not biased in any of the species.
\end{abstract}

Key words: Desterro Environmental Conservation Unit, effects of temperature and rainfall, sex ratio, small rodents, reproduction

\section{Resumo}

Dinâmica populacional de Euryoryzomys russatus e Oligoryzomys nigripes (Rodentia, Cricetidae) em uma área de Mata Atlântica na Ilha de Santa Catarina, sul do Brasil. A dinâmica populacional e aspectos reprodutivos de duas espécies de roedores da família Cricetidae, Euryoryzomys russatus e Oligoryzomys nigripes, foram estudados durante 24 meses em uma área de Mata Atlântica do sul do Brasil. Euryoryzomys russatus apresentou flutuação populacional dependente de densidade e o recrutamento foi associado positivamente com a temperatura. Oligoryzomys nigripes apresentou a menor abundância, a maior flutuação populacional e o menor tempo de permanência. Verificou-se correlação negativa da abundância e da sobrevivência com a temperatura. A proporção sexual não desviou do esperado 1:1 em nenhuma das espécies.

Unitermos: efeitos da temperatura e pluviosidade, pequenos roedores, proporção sexual, reprodução, Unidade de Conservação Ambiental Desterro 


\section{Introduction}

In the last decades, anthropic pressure over natural environments on Santa Catarina Island, resulting from human population growth, have led to overexploitation and destruction of the Atlantic Forest. The continuous forest landscape of the past has been turned into isolated patches, ranging over less than $10 \%$ of the island territory (Caruso, 1990). This fragmentation process may bring consequences such as biodiversity loss and vulnerability of the remaining populations (Viana, 1990).

Comprehension of the natural population dynamics and the possibility of prediction and control over processes that affect these populations are both essential for the species conservation, mainly in fragmented areas (Quental et al., 2001; Townsend et al., 2006). Small mammals have been used as indicators of the effects of urban and agricultural expansion over the biodiversity, and also as indicators of habitat quality, throughout studies that have investigated how species remain in landscapes with forest patches and altered areas (Pardini et al., 2005; Umetsu and Pardini, 2007). However, until recently the majority of the studies about mammals on Santa Catarina Island were limited to species occurrence and distribution lists. Only in the last decade have studies been conducted with a focus on the ecology of marsupials (Goulart et al., 2006; Graipel and Santos Filho, 2006) and small rodents (Graipel et al., 2006).
In this context, aiming to deepen the knowledge of population dynamics of small rodents, we studied a community of small mammals in a protected area of Santa Catarina Island. Our objectives were (1) to describe the reproductive and populational aspects of Rice Rats (Euryoryzomys russatus) and Pygmy Rice Rats (Oligoryzomys nigripes) and (2) to verify the influence of the intrinsic populational factors (recruitment and survivorship) and extrinsic factors (temperature and rainfall) on the population parameters.

\section{Materials and Methods}

\section{Study area}

The study was conducted at the Desterro Environmental Conservation Unit (DECU) $\left(4.9 \mathrm{~km}^{2}\right.$; $27^{\circ} 52^{\prime} \mathrm{S}, 48^{\circ} 50^{\prime} \mathrm{W}$ ), located in the central region of Santa Catarina Island in southern Brazil. The predominant vegetation is dense ombrophilous forest in various stages of secondary regeneration, with a few areas in the primary stage (CECCA, 1997). The climate is humid mesothermic with warm summers (Caruso, 1990). During this study, the maximum mean temperature was recorded in January $2006\left(26^{\circ} \mathrm{C}\right)$ and the minimum in July $2005\left(17^{\circ} \mathrm{C}\right)$. The rainiest month was February $2005(223 \mathrm{~mm})$ and the driest was June $2006(31 \mathrm{~mm})$ (Figure 1). Three areas were sampled: pioneer formation,

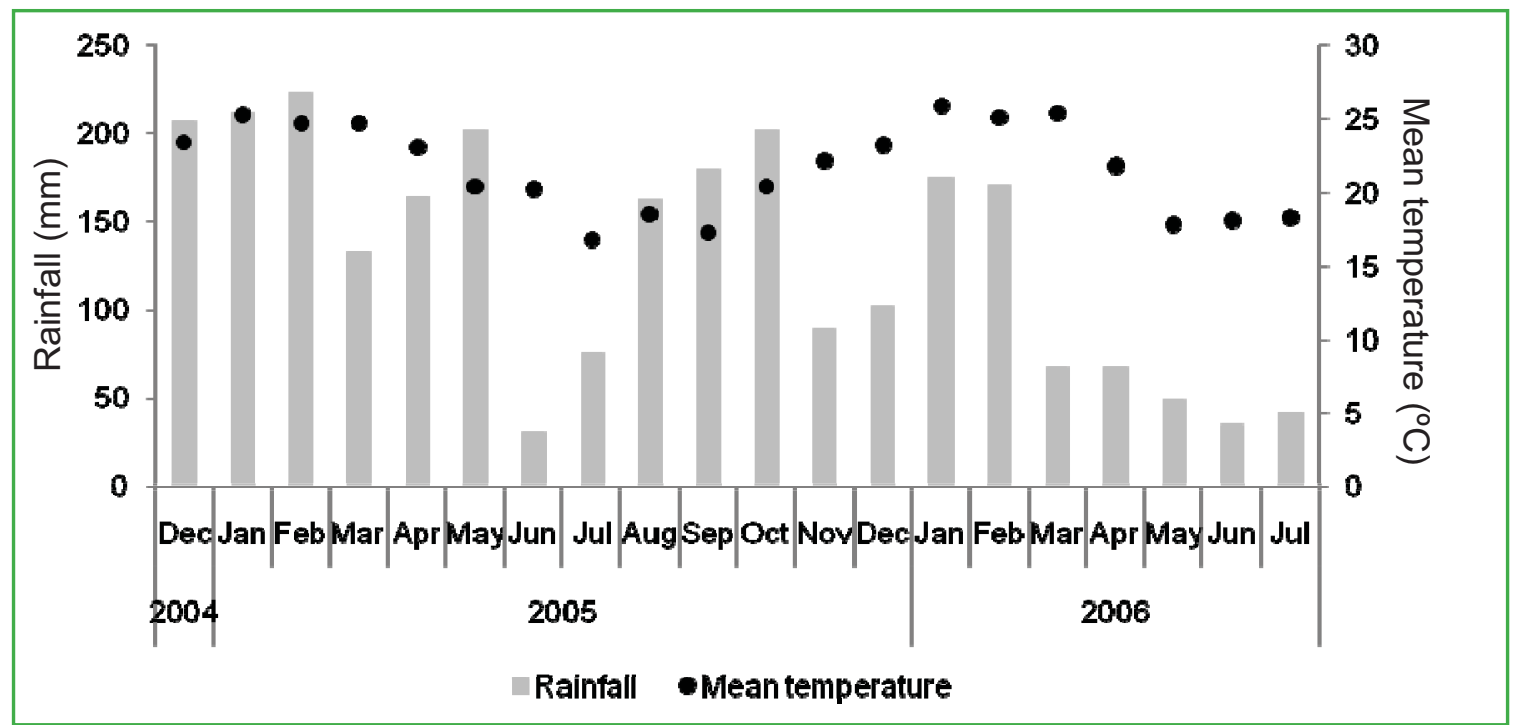

FIGURE 1: Monthly variation in rainfall and temperature from December 2004 to July 2006 in São José, 10km away from the Desterro Environmental Conservation Unit in Santa Catarina, southern Brazil (Source: INMET/EPAGRI). 
gallery forest, and slope forest. The pioneer formation is characterized by a clearing remaining from an old fire-cleared area of pastureland now covered with herbaceous and shrubby species (Andropogon spp., Dodonea viscosa, Bacharis spp. and Eupatorium spp.). The gallery forest and slope forest are characterized by vegetation in an advanced stage of regeneration (40 years of abandonment after selective tree harvesting), located in the surroundings of a river and at the water divide, respectively. The predominant arboreal species are Cedrela fissilis, Ocotea catharinensis, Schizolobium parahyba and Miconia cabucu reaching heights of up to 20-25m, with a sub-forest composed predominantly of Euterpe edulis, Bactris sp., Cyatea spp. and Dicksonia sellowiana (Klein, 1981).

\section{Field methods}

Between August 2004 and July 2006, 24 monthly samplings were done on three consecutive nights each. The animals were captured using 80 live traps $(260 \times 120$ $\mathrm{x} 90 \mathrm{~mm})$. A transect with 16 capture stations $10 \mathrm{~m}$ apart from each other was installed in each sampled area (pioneer formation, gallery forest, and slope forest). In the pioneer formation, each capture station consisted of a trap on the ground. In the other areas, each capture station consisted of 2 traps, one on the ground and the other in the understory at a height of about $2 \mathrm{~m}$ (Graipel et al., 2003) or in the canopy (Graipel, 2003a) above 5m. The traps were baited with slices of banana covered with peanut butter.

The first time the individuals were captured, we marked them by cutting a distal phalanx (Fullagar and Jewell, 1965). In each capture, the species and individual were identified and the sex and reproductive condition determined. The females were considered reproductively active when they presented a perforated vagina or were pregnant or lactating. Individuals that died during the study were deposited in the Scientific Mammal Collection of the Federal University of Santa Catarina (Department of Ecology and Zoology, Center for Biological Sciences).

\section{Data analyses}

We used the Minimum Number Known Alive (MNKA) as an abundance index to evaluate the fluctuation of the populations (Krebs, 1966). The recruitment rate was calculated by dividing the number of unmarked individuals captured during sampling by the total number of marked and unmarked individuals captured during the same sampling event. The survival rate was obtained by dividing the number of known surviving individuals in the months following the sampling by the MNKA of the sampling (Graipel et al., 2006).Using Spearman's Correlation Coefficient (Zar, 1999), a correlation was tested between the abundance of each species and the intrinsic (survival rate and recruitment) and extrinsic factors (average monthly temperature and accumulated monthly rainfall), as well as between intrinsic and extrinsic factors. Because the effect of intrinsic and extrinsic factors on the abundance of populations is not always immediate and is usually indirect (Bergallo and Magnusson, 1999), we tested the existence of correlations using values of the factors of the corresponding month and the two previous months. Due to the absence of information, the samplings collected from September to November 2004 were discarded from the correlation analyses which involved extrinsic factors.

To assess the influence of the entrance of juvenile individuals into the population, we checked the existence of a correlation between the monthly average head length and the MNKA and the recruitment rate, based on Spearman's Correlation Coefficient (Zar, 1999).

The sexual structure of the populations was evaluated by testing the estimated proportion of males and females using the chi-square test for equal expected proportions. In the case of samples of less than 40, Yates's correction was used (Zar, 1999). The number of male and female individuals present throughout the study was estimated using the formula $N=n / p$, where $N=$ number of male or female individuals in the population, $n=$ number of captured male or female individuals, and $p=$ minimum capturability of males or females (modified from Begon, 1979). The minimum capturability index $(p)$ was estimated from the following formula according to Hilborn et al. (1976): $p=\left[\sum_{\mathrm{i}=1}^{\mathrm{n}}(\mathrm{nc}-2 / \mathrm{np})\right] / \mathrm{N}$; where $\mathrm{nc}=$ number of captures of an individual, $\mathrm{np}=$ number of sampling events in which the individuals could have been captured, excluding the first and last sampling 
event, and $\mathrm{N}=$ number of individuals in the sample. The reproductive activity of the species was verified from the proportion of reproductively active females in each sampling event. The reproductive condition of the males was not considered, since the assessment of the position of the testes is subjective and is influenced by external factors, such as temperature, especially in small species (Bergallo and Magnusson, 1999).

The permanence time of males and females was obtained by adding up the number of days between the first and last capture of each individual, considering only those captured in at least two samplings. Differences in permanence time were analyzed by Mann-Whitney's U test (Zar, 1999). Using Fisher's exact test, a difference was tested in the number of resident and transitory individuals between the sexes. Individuals were considered resident when they remained in the study area for more than 20 days (the shortest interval between two consecutive sampling periods).

The meteorological data were provided by the Santa Catarina Institute of Meteorology (INMET/ EPAGRI) and refer to the São José station $10 \mathrm{~km}$ from DECU (Desterro Environmental Conservation Unit).

Species with few captures, such as Sooretamys angouya, Micoureus paraguayanus and Juliomys sp. were not considered in any analysis. Data obtained on Akodon montensis are presented in Antunes et al. (2009).

\section{Results}

With a sampling effort of 5,760 trap nights, 3,456 on the ground and 2,304 in the understory or arboreal strata, 363 captures were made, representing a success rate of $6.3 \%$. We captured five species of small rodents, A. montensis (Grass Mice), E. russatus, Juliomys sp. (Lesser Wilfred's Mouse), O. nigripes, S. angouya (Rice Rat) and the marsupial M. paraguayanus (Long Furred Woolly Mouse Opossum).

\section{Euryoryzomys russatus}

This species was captured only on the ground. Forty-four captures of 26 individuals were made in the gallery forest and the water divide, resulting in a success rate of $1.3 \%$. The abundance was slightly greater than that observed for $O$. nigripes, but the population fluctuation was lower (Table 1). Survival and recruitment rates reached the highest mean values among the species studied (Table 1).

Population peaks were observed in November and December 2004, and from May to July and October to November 2005 (Figure 2A). Abundance was negatively correlated with the recruitment $\left(r_{s}=-0.732, P<0.002, n\right.$ $=15$ ), with the temperature of the corresponding month $\left(r_{s}=-0.6051, P<0.008, n=18\right)$, with the previous month $\left(r_{s}=-0.627, P=0.007, n=17\right)$, and with two months previous $\left(r_{s}=-0.565, \mathrm{P}<0.023, \mathrm{n}=16\right)$. The recruitment rate was directly correlated with the temperature of the previous month $\left(\mathrm{r}_{\mathrm{s}}=0.801, \mathrm{P}<0.002, \mathrm{n}=12\right)$. There was no correlation between the mean head length and MNKA and the recruitment rate $(\mathrm{P}>0.05)$. The sex ratio was not biased $\left(\chi^{2}=1.62\right.$, d.f. $\left.=1, P=0.203\right)$. Reproductively active females were found in September and December 2004, in July, October and December 2005, and in June 2006 (Figure 2B). The average permanence time was 69.2 days, without a distinction between the sexes $(\mathrm{P}=$

TABLE 1: Average minimum number of animals known alive (MNKA), survival rate and recruitment rate of small rodents in the Desterro Environmental Conservation Unit, Santa Catarina, southern Brazil, from September 2004 to July 2006. $\bar{x}=$ average; SD = standard deviation; CV = coefficient of variation.

\begin{tabular}{lccccccccc}
\hline \multirow{2}{*}{ Species } & \multicolumn{3}{c}{ MNKA } & \multicolumn{3}{c}{ Survival rates } & \multicolumn{4}{c}{ Recruitment rates } \\
\cline { 2 - 10 } & $\overline{\mathrm{x}}$ & SD & CV & $\overline{\mathrm{x}}$ & SD & CV & $\overline{\mathrm{x}}$ & SD & CV \\
\hline Euryoryzomys russatus & 2.64 & 1.84 & 69.79 & 0.62 & 0.38 & 61.30 & 0.70 & 0.29 & 41.00 \\
Oligoryzomys nigripes & 2.33 & 2.35 & 100.73 & 0.44 & 0.36 & 82.26 & 0.55 & 0.43 & 76.70 \\
\hline
\end{tabular}




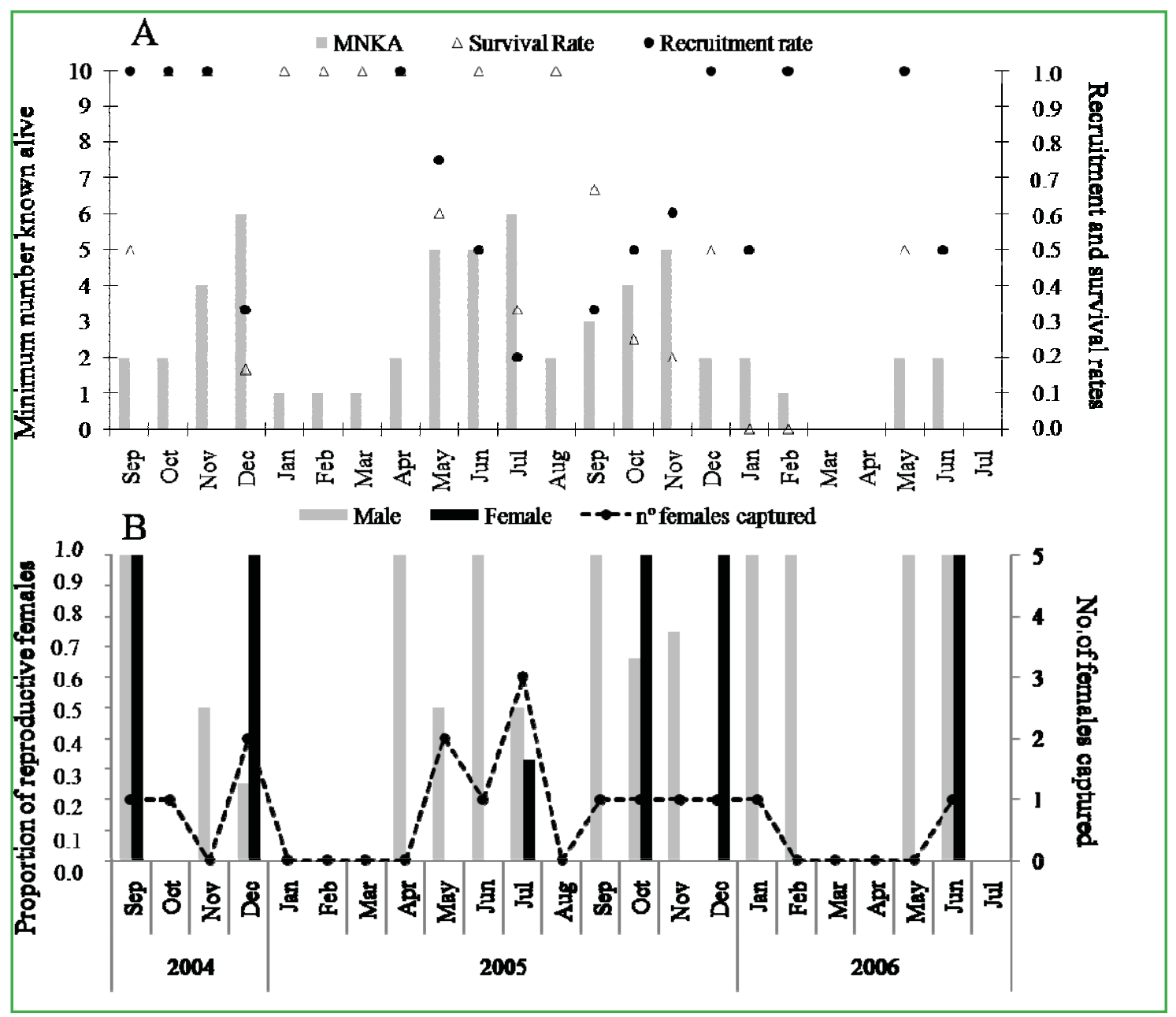

FIGURE 2: Monthly variation (A) in abundance, survival and recruitment rates and (B) in the proportion of reproductively active individuals of Euryoryzomys russatus in the Desterro Environmental Conservation Unit, Santa Catarina, southern Brazil, from September 2004 to July 2006.

0.353) (Table 2). No difference was found between the sexes in terms of the proportion of resident and transitory individuals $(\mathrm{P}=0.103)$ (Table 2$)$.

\section{Oligoryzomys nigripes}

The 37 captures of 18 individuals occurred only in the clearing, on the ground, with a success rate of $1.1 \%$. Oligoryzomys nigripes presented the highest population fluctuation among the species studied (Table 1). This species was detected in the study area only from May 2005 to January 2006 and in June and July 2006, with population peaks in August, September and October 2005 and declining numbers between February and May 2006 (Figura 3A). A negative correlation was identified between abundance and temperature of the previous month $\left(\mathrm{r}_{\mathrm{s}}=-0.762, \mathrm{P}<0.004, \mathrm{n}=12\right)$. The survival rate was inversely correlated to the temperature of the two previous months $\left(\mathrm{r}_{\mathrm{s}}=-0.774, \mathrm{P}<0.015, \mathrm{n}=9\right)$. No correlation was found between the mean head length and MNKA and the recruitment rate $(\mathrm{P}>0.05)$. The sex ratio followed the expected one $\left(\chi^{2}=0.321\right.$, d.f. $=1, \mathrm{P}=$ $0.57)$. Reproductively active females were detected only in the months of September and October 2005 and in July 2006 (Figure 3B). Oligoryzomys nigripes showed the shortest mean permanence time among the species studied here, i.e., 56.4 days, with no distinction between the sexes $(\mathrm{P}=0.305)$ (Table 2). We found no difference between the sexes in terms of the proportion of resident and transitory individuals $(\mathrm{P}=1.000)$ (Table 2$)$. 

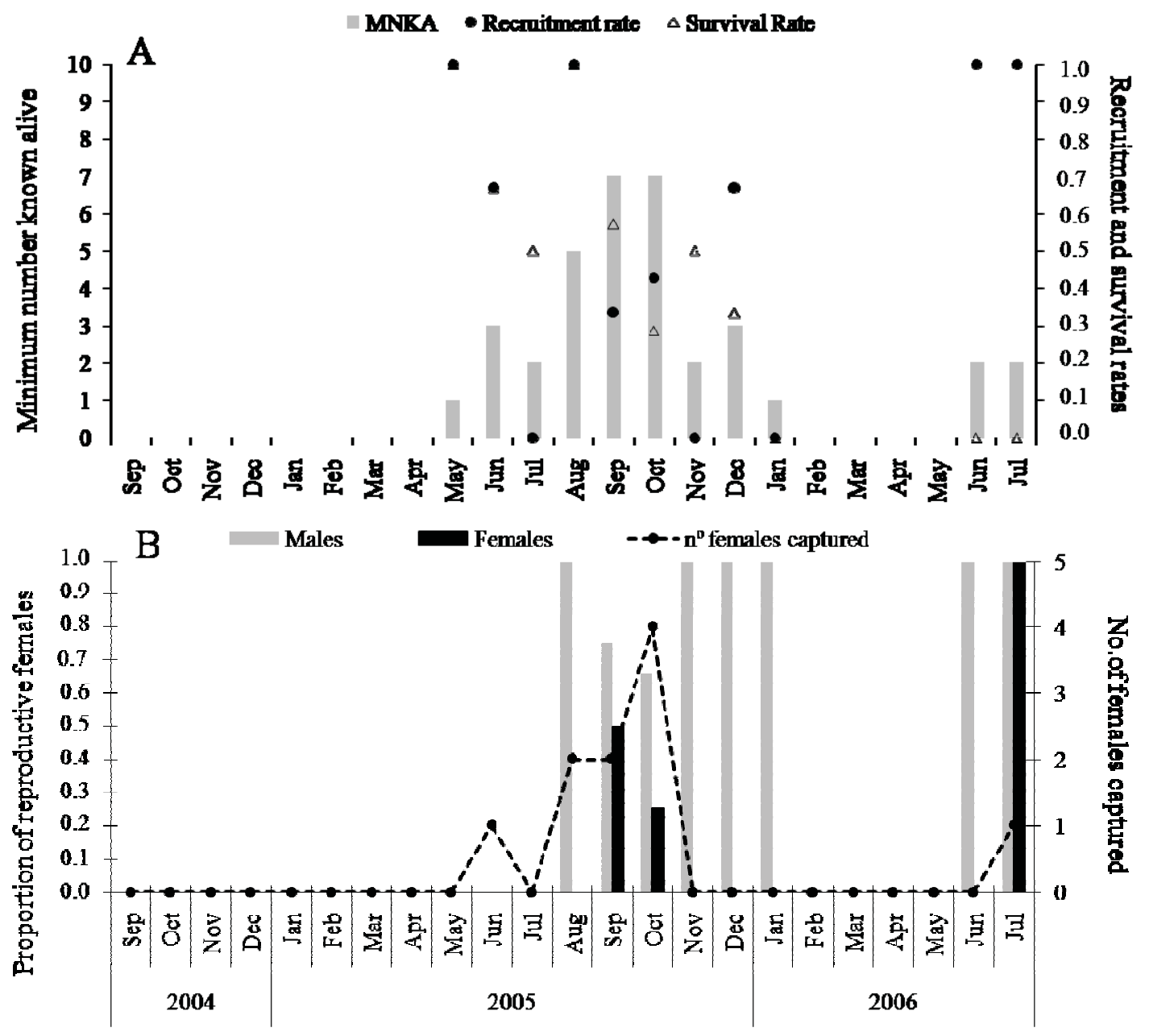

FIGURE 3: Monthly variation (A) in abundance, survival and recruitment rates and (B) in the proportion of reproductively active individuals of Oligoryzomys nigripes in the Desterro Environmental Conservation Unit, Santa Catarina, southern Brazil, from September 2004 to July 2006.

TABLE 2: Mean permanence time and analysis of small rodent individuals residing in the Desterro Environmental Conservation Unit, Santa Catarina, southern Brazil, from September 2004 to July 2006. $\bar{x}=$ mean permanence time in days; $\mathrm{SD}=$ standard deviation; Tmax. = maximum permanence time in days; $\mathrm{Z}(\mathrm{U})=$ value of $\mathrm{Z}$ for the Mann-Whitney $\mathrm{U}$ test with regard to differences in permanence time between males and females; $\mathrm{p}=$ level of significance for the Mann-Whitney $\mathrm{U}$ test; $\mathrm{N}=$ number of resident individuals; $\% \mathrm{M}=$ percentage of resident males; $\% \mathrm{~F}=$ percentage of resident females; $\mathrm{p}^{\prime}=$ level of significance for Fisher's exact test with regard to differences between resident and transitory individuals of both sexes.

\begin{tabular}{lcccccccc}
\hline \multicolumn{1}{c}{ Species / Sex } & $\overline{\mathbf{x}} \pm \mathrm{SD}$ & $\mathbf{T m a x}$. & $\mathbf{Z}(\mathbf{U})$ & $\mathbf{p}$ & $\mathbf{N}$ & $\mathbf{\% M}$ & $\mathbf{\% F}$ & $\mathbf{p}$ \\
\hline Euryoryzomys russatus & $69.2 \pm 67.2$ & 220 & & & 11 & & & \\
Male & $82.1 \pm 92.1$ & 220 & 0.9286 & 0.353 & 5 & 29.4 & 66.7 & 0.103 \\
Female & $54.0 \pm 12.7$ & 77 & & & 6 & & & \\
Oligoryzomys nigripes & $56.4 \pm 20.2$ & 79 & & & 10 & & & \\
Male & $52.7 \pm 20.1$ & 79 & 1.0256 & 0.305 & 7 & 58.3 & 50 & 1.000 \\
Female & $65 \pm 21.7$ & 78 & & & 3 & & & \\
\hline
\end{tabular}




\section{Discussion}

\section{Euryoryzomys russatus}

The abundance of E. russatus declined during the warmest months, which may be explained by the negative correlation found between MNKA and temperature. Recruitment and temperature were also negatively correlated in the corresponding month. And recruitment was positively correlated with temperature of the previous month. The arrival of individuals into the population appeared to be more numerous in the warmest months, but they did not remain there. This may be a case of density dependence, where the increased arrival of individuals in the population exceeded the carrying capacity of the environment, resulting in a decline in the survival rate. For this species, Graipel et al. (2006) observed a negative correlation between density and survival rates, corroborating the hypothesis of density dependence. In contrast, other studies have observed little population fluctuation throughout the year (Bergallo, 1994; Graipel, 2003b).

Reproductive activity in this species was detected only during six months scattered along the two years. In contrast, other studies of this species found continuous reproduction throughout the year (Bergallo, 1995; Graipel, 2003b; Graipel et al., 2006). Possibly, this pattern is repeated in the DECU, but may have gone undetected by us due to the low number or absence of female captures in many sampling periods. The permanence time for this species was 69.2 days and no difference was found between the sexes, corroborating the findings of Graipel et al. (2006) and Graipel (2003b). Moreover, no difference was found between the sexes in terms of the number of resident individuals, and the sex ratio was not biased, in line with the findings of Graipel (2003b). This may be a reflex of the monogamous reproductive system adopted by this species (Bergallo and Magnusson, 2004).

\section{Oligoryzomys nigripes}

This species showed the lowest abundance of the species studied here, which is consistent with the findings of Feliciano et al. (2002) and Graipel (2003b).
The population levels peaked in the cold and dry months, reaching null values during the warmest months, coinciding with the reports of Feliciano et al. (2002), Graipel (2003b) and Graipel et al. (2006). Feliciano et al. (2002) suggest that the population increase in this period is connected to the greater availability of food resources for this species, especially of grass seeds (Emmons and Feer, 1999). The reduction of the population size in the warm months is also revealed by the existence of a negative correlation between abundance and temperature of the previous months and between the survival rate and temperature two months previously. This pattern may be related with the dispersal of individuals to adjacent areas in search of food resources (Oliveira, 1985).

Graipel et al. (2006) found reproductive $O$. nigripes females from May to December, and the reproductive activity in the DECU coincided with this period. On the other hand, Fonseca and Kierulff (1989) reported that this species reproduces throughout the year. O. nigripes presented a shorter permanence time than the other species, i.e., 56.4 days, with no difference in permanence between the sexes, which is consistent with other studies (Graipel, 2003b; Graipel et al., 2006). The sexes showed no difference in the number of resident individuals, unlike the findings of Graipel et al. (2006), who reported more resident females. The sex ratio was not biased, unlike the report of Graipel et al. (2006), who found a male-biased sex ratio. However, it is worth pointing out that these authors tested the sex ratio of captured individuals and not necessarily of the population. This may lead to distorted findings if there is a difference in capturability between the sexes.

From the standpoint of conservation, the DECU contains species sensitive to environmental changes (e.g., E. russatus and Juliomys sp.) and more tolerant species (e.g., A. montensis and O. nigripes) (Umetsu and Pardini, 2007), but the population of $A$. montensis showed a far higher abundance than the other species (Antunes et al., 2009). Assemblages of small rodents can undergo alterations in the abundance and composition of species in response to environmental perturbations (Vieira, 1999; Briani et al., 2004), through modifications in the structure of microhabitats and in the availability of resources (Lambert et al., 2006). Upon recovery of 
the vegetation, there is a sequence of local cycles of colonization and extinction of small mammal species (Torre and Díaz, 2004), with species exclusively of the initial stages of regeneration, others exclusively of the final stages, and some that occur in all the stages undergoing alterations only in their abundance (Briani et al., 2004). The DECU was created in 1996, in an area that had previously been subjected to selective tree harvesting and to extensive cattle ranching, which altered the structure of the habitat. From the time of the area's protection, the vegetation has been gradually regenerating, together with the assemblage of small mammals which may have undergone alterations. In the area of pioneer formation, which has been subjected to successive burning, the vegetation is still in an initial phase of regeneration. This area was colonized only by $O$. nigripes, a species occurring principally in open vegetation formations (Oliveira and Bonvicino, 2006). In the other areas, the current stage of the regeneration of the vegetation already allowed the colonization and establishment of species considered demanding. However, the population of E. russatus still occurs in low abundance, while the A. montensis population is more abundant (Antunes et al., 2009). It is expected that both species should present similar abundances in pristine or well-conserved areas (Graipel et al., 2006) or that E. russatus can be found in higher abundances (Pardini et al., 2005), suggesting that, in the DECU, $A$. montensis is probably still undergoing alterations in its abundance.

\section{Acknowledgements}

The authors are indebted to the Federal University of Santa Catarina for giving permission for this study in the Desterro Environmental Conservation Unit. Special thanks are also due to Silvânio G. Costa for his logistic support, to Diogo A. Tschoecke and Hugo B. Mozerle for their help in the field work, to Carlos H. Salvador, Jorge J. Cherem and Tânia T. Castellani for their constructive critiques and comments, and to Carlos A. Zucco for English language support.

\section{References}

Antunes, P. C.; Campos, M. A. A.; Oliveira-Santos, L. G. R.; Graipel, M. E. 2009. Population dynamics of Akodon montensis (Rodentia, Cricetidae) in the Atlantic Forest of Southern Brasil. Mammalian Biology (in press).

Begon, M. 1979. Investigating animal abundance: Capturerecapture for biologists. Edward Arnold, London, UK, 97pp.

Bergallo, H. G. 1994. Ecology of a small mammal community in an Atlantic Forest area in southeastern Brazil. Studies on Neotropical Fauna and Environment, 29: 197-217.

Bergallo, H. G. 1995. Comparative life-history characteristics of two species of rats, Proechimys iheringi and Oryzomys intermedius, in an Atlantic Forest of Brazil. Mammalia, 59: 51-64.

Bergallo, H. G.; Magnusson, W. E. 1999. Effects of climate and food availability on four rodent species in southeastern Brazil. Journal of Mammalogy, 80: 472-486.

Bergallo, H. G.; Magnusson, W. E. 2004. Factors affecting the use of space by two rodent species in Brazilian Atlantic forest. Mammalia, 68: 121-132.

Briani, D. C.; Palma, A. R. T.; Vieira, E. M.; Henriques, R. P. B. 2004. Post-fire sucession of small mammal in the Cerrado of central Brazil. Biodiversity and Conservation, 13:1023-1037.

Caruso, M. M. L. 1990. O desmatamento na Ilha de Santa Catarina de 1500 aos dias atuais. $2^{\text {nd }}$ ed. Editora da UFSC, Florianópolis, Brasil, 158pp.

CECCA (Centro de Estudos, Cultura e Cidadania). 1997. Unidades de Conservação e áreas protegidas da Ilha de Santa Catarina: Caracterização e legislação. Editora Insular, Florianópolis, Brasil, 160pp.

Emmons, L.; Feer, F. 1999. Neotropical rainforest mammals: A field guide. $3^{\text {rd }}$ ed. University of Chicago Press, Chicago, USA, 307pp.

Feliciano, B. R.; Fernandez, F. A. S.; Freitas, D.; Figueiredo, M. S. L. 2002. Population dynamics of small rodents in a grassland between fragments of Atlantic Forest in southeastern Brazil. Mammalian Biology, 67: 304-314.

Fonseca, G. A. B.; Kierulff, M. C. M. 1989. Biology and natural history of Brazilian Atlantic Forest small mammals. Bulletin of the Florida State Museum, Biological Sciences, 34: 99-152.

Fullagar, P. J.; Jewell, P. A. 1965. Marking small rodents and the difficulties of using leg rings. Journal of Zoology, 147: 224-228.

Goulart, F. V. B.; Souza, F. L.; Pavese, H. B.; Graipel, M. E. 2006. Estrutura populacional e uso do estrato vertical por Micoureus paraguayanus (Didelphimorphia, Didelphidae) em fragmentos de Floresta Atlântica de planície no sul do Brasil. Biotemas, 19: 4553.

Graipel, M. E. 2003a. A simple ground-based method for trapping small mammals in the forest canopy. Mastozoologia Neotropical, 10: $177-181$.

Graipel, M. E. 2003b. Contribuição ao estudo da mastofauna do estado de Santa Catarina, sul do Brasil. PhD Thesis, Pontificia Universidade Católica do Rio Grande do Sul, Brasil, 226pp.

Graipel, M. E.; Cherem, J. J.; Miller, P. R. M.; Glock, L. 2003. Trapping small mammals in the forest understory: a comparison of three methods. Mammalia, 67: 551-558. 
Graipel, M. E.; Cherem, J. J.; Monteiro-Filho, E. L. A.; Glock, L. 2006. Dinâmica populacional de marsupiais e roedores no Parque Municipal da Lagoa do Peri, Ilha de Santa Catarina, sul do Brasil. Mastozoología Neotropical, 13: 31-49.

Graipel, M. E.; Santos Filho, M. dos. 2006. Reprodução e dinâmica populacional de Didelphis aurita Wied-Neuwied (Mammalia, Didelphimorphia) em ambiente periurbano na Ilha de Santa Catarina, sul do Brasil. Biotemas, 19: 65-73.

Hilborn, R.; Redfield, J. A.; Krebs, C. J. 1976. On the reability of enumeration for mark and recapture census of voles. Canadian Journal of Zoology, 54: 1019-1024.

Klein, R. M. 1981. Fisionomia, importância e recursos da vegetação do Parque Estadual da Serra do Tabuleiro. Sellowia, 33: 5-54.

Krebs, C. J. 1966. Demographic changes in fluctuating populations of Microtus californicus. Ecological Monographs, 36: 239-273.

Lambert, T. D.; Malcolm, J. R.; Zimmerman, B. M. 2006. Amazonian small mammal abundances in relation to habitat structure and resource abundance. Journal of Mammalogy, 87:766-776.

Oliveira, L. F. B. 1985. Estrutura e ordenação espaço-temporal de uma congregação de roedores no sul da planície costeira do Rio Grande do Sul (Mammalia, Rodentia, Cricetidae). MSc Thesis, Universidade Federal do Rio Grande do Sul, Brasil, 143pp. Oliveira, J. A.; Bonvicino, C. R. 2006. Ordem Rodentia. Pp. $347-$ 400 in Mamíferos do Brasil (N. R. Reis, A. L. Peracchi, W. A. Pedro, I. P. Lima, eds.). Londrina.
Pardini, R.; Souza, S. M. de; Braga-Neto, R.; Metzger, J. P. 2005. The role of forest structure, fragment size and corridors in maintaining small mammal abundance and diversity in na Atlantic Forest landscape. Biological Conservation, 124: 253-266.

Quental, T. B.; Fernandez, F. A. S.; Dias, A. T. C.; Rocha, F. S. 2001. Population dynamics of the marsupial Micoureus demerarae in small fragments of Atlantic Coastal Forest in Brazil. Journal of Tropical Ecology, 17: 339-352.

Torre, I.; Díaz, M. 2004. Small mammal abundance in Mediterranean post-fire habitats: a role for predators? Acta Oecologica, 25:137143.

Townsend, C. R.; Begon, M.; Harper, J. L. 2006. Fundamentos em Ecologia. $2^{\text {nd }}$ ed. Editora Artmed, Porto Alegre, Brasil, 592pp.

Umetsu, F.; Pardini, R. 2007. Small mammals in a mosaic of Forest remnants and anthropogenic habitats - evaluating matrix quality in a Atlantic forest landscape. Landscape Ecology, 22: 517530.

Viana, V. M. 1990. Biologia e manejo de fragmentos de florestas naturais. Anais do $6^{\circ}$ Congresso Florestal Brasileiro, Curitiba, Brasil, p.113.

Vieira, E. M. 1999. Small mammal communities and fire in the Brazilian Cerrado. Journal of Zoology, 249:75-81.

Zar, J. H. 1999. Biostatistical analysis. $4^{\text {th }}$ ed. Prentice-Hall, New Jersey, USA, 663pp. 